\title{
PENGEMBANGAN KAWASAN RUMAH PANGAN LESTARI UNTUK MASYARAKAT DESA GUMANTAR KECAMATAN KAYANGAN KABUPATEN LOMBOK UTARA
}

\author{
Taslim Sjah*), Asri Hidayati, Jayaputra \\ Fakultas Pertanian Universitas Mataram \\ Jalan Majapahit 62 Mataram \\ *alamat korespondensi: t.sjah2@gmail.com
}

\begin{abstract}
ABSTRAK
Kabupaten Lombok Utara, termasuk Desa Gumantar, Kecamatan Kayangan, sedang giat melakukan pembangunan ekonomi dengan memanfaatkan sumberdaya yang dimilikinya, seperti lahan pekarangan, ketersediaan air, kesesuaian iklim, dan ketersediaan sumber tenaga kerja keluarga petani. Kegiatan ini dilakukan untuk mengembangkan Kawasan Rumah Pangan Lestari untuk mendukung ketahanan pangan masyarakat lahan kering di Desa Gumantar Kecamatan Kayangan Kabupaten Lombok Utara, melalui kegiatan penyuluhan dalam beberapa aspek pemanfaatan sumberdaya alam dan manusia, serta penerapan iptek budidaya tanaman pekarangan. Pelaksanaan kegiatan dilakukan dalam bentuk ceramah, diskusi, dan praktik tentang aspek-aspek yang disuluhkan. Materi pelaksanaan kegiatan disampaikan langsung oleh tim pelaksana yang sekaligus menjadi narasumber, sehingga kegiatan dapat berjalan secara efektif. Hasil kegiatan dinilai positif dengan proses yang berlangsung secara efektif. Hasil evaluasi ini menyarankan bahwa kegiatan serupa ini perlu dilakukan kembali di lokasi yang sama atau berbeda, karena potensi dan peluang untuk pengembangan program Kawasan Rumah Pangan Lestari masih terbuka.
\end{abstract}

Kata Kunci : Kawasan Rumah Pangan Lestari, Lahan Kering, Ketahanan Pangan, Pertanian Pekarangan

\section{PENDAHULUAN}

Indonesia terus menerus
membangun bidang eonomi,
termasuk membangun sektor
pertanian, agar dapat mencukupi
produksi untuk kebutuhan sendiri
maupun untuk dijual ke pasar,

sehingga diperoleh pendapatan bagi pelakunya (Menteri Pertanian RI, 2015). Peningkatan produksi pertanian dapat ditempuh dengan berbagai cara termasuk melakukan intensifikasi pertanian, ekstensifikasi pertanian, diversfikasi pertanian, dan rehabilitasi lahan pertanian (Sjah, 
2010). Intensifikasi pertanian berarti menambah penggunaan input pertanian pada luas lahan yang sama. Ektensifikasi pertanian merupakan upaya peningkatan produksi pertanian melalui perluasan areal penanaman. Diversifikasi pertanian melakukan pengusahaan berbagai tanaman pada lahan-lahan pertanian yang sesuai atau memungkinkan sehingga terjadi efisiensi penggunaan sumberdaya alam dan manusia. Rehabilitasi lahan merupakan upaya untuk melakukan perbaikan kondisi lahan sehingga lahan menjadi lebih produktif dari pada sebelumnya. Pada lahan kering seperti lahan pekarangan masyarakat dapat dimanfaatkan seoptimal mungkin dengan kombinasi berbagai usaha yang baru saja disebutkan. Misalnya, pada lahan tersebut dapat ditanami dengan berbagai tanaman (diversifikasi tanaman) sebagai upaya ekstensifikasi pada lahan yang kurang dimanfaatkan, lalu pada tanaman-tanaman tersebut ditingkatkan penggunaan inputnya (intensifikiasi tanaman), sambil memperbaiki kondisi lahan pekarangan tersebut (rehabilitasi lahan). Dengan demikian, semua usaha peningkatan produksi pertanian ini dilakukan secara terpadu pada lahan kering pekarangan. Menurut Saragih (2004) pembangunan pertanian lebih bagus lagi bila dibangun secara terpadu dalam sistem agribisnis, yang dalam hal ini dianjurkan agar pelaku usaha melakukan kegiatan pengolahan dan peningkatan nilai tambah dari produk pertanian yang dihasilkannya.

Setelah usahatani, maka selanjutnya adalah melakukan kegiatan panen dan pasca panen, serta pengolahan hasil panen. Kegiatan lanjutan ini perlu dilakukan dengan beberapa alasan. Untuk mengantisipasi meningkatkan produksi pertanian sebagai akibat dari usaha intensif dan aneka ragam pada lahan pekerangan tersebut maka produk pertanian tersebut perlu diolah untuk memperoleh masa simpan yang lebih lama. Menurut Sjah (2010) pengolahan juga penting untuk meningkatkan 
nilai tambah produk dalam bentuk yang sesuai, selain dengan adanya nilai waktu, yang keduanya menunjang untuk peningkatan nilai tempat dari produk tersebut untuk dapat dipasarkan ke pusat-pusat konsumsi pada masyarakat yang bersedia membeli dengan harga lebih tinggi untuk memiliki produk tersebut.

Masyarakat lahan kering di Desa Gumantar, Kecamatan Kayangan, Kabupaten Lombok Utara, memiliki lahan pekarangan (BPS Lombok Utara, 2016) yang potensial untuk dimanfaatkan dengan berbagai tanaman semusim maupun tanaman tahunan, khususnya tanaman pangan. Dengan penanaman tanaman pangan, seperti sayuran dan buah-buahan di pekarangan maka pengelolaan demikian merupakan semacam program yang dijalankan pemerintah saat ini, yaitu program kawasan rumah pangan lestari atau lebih populer dengan singkatannya KRPL (Badan Litbang Pertanian RI, 2017). Situasi di Desa Gumantar, Kecamatan Kayangan secara lebih eksplisit dapat disampaikan sebagai berikut:

1. Ada beberapa ruang pada pekarangan rumah masyarakat yang belum dan sangat potensial untuk dimanfaatkan dengan berbagai tanaman yang sesuai.

2. Potensi alam (lingkungan tanah dan iklim) sesuai untuk berbagai tanaman, termasuk tanaman pangan seperti sayuran, yang dapat langsung dimanfaatkan untuk memenuhi kebutuhan keluarga setempat atau pun untuk dijual ke pasar.

3. Ketika usahatani di pekarangan dengan berbagai tanaman yang cocok berhasil memproduksi hingga melebihi kebutuhan keluarga maka diperlukan kegiatan pengolahan hasil termasuk penanganan ringan untuk memperpanjang masa simpan.

4. Pemasaran merupakan hal penting untuk ditangani agar kegunaan produk meningkatkan dalam bentuk, waktu, tempat, dan kepemilikan. 
5. Kemampuan pelaku usaha dinilai terbatas, seperti belum melakukan usaha pengolahan hasil pertanian dan belum biasa memasarkan produk

Tujuan kegiatan ini secara umum adalah untuk meningkatkan ketahanan pangan masyarakat lahan kering Desa Gumantar, Kecamatan Kayangan, Kabupaten Lombok Utara. Peningkatan ketahanan pangan ini diharapkan dicapai dalam aspek produksi, akses, dan konsumsi pangan. Tulisan ini melaporkan tentang pelaksanaan kegiatan terkait dengan pencapain tujuan tersebut dan hasil-hasil yang dicapai. Kegiatan ini diharapkan bermanfaat bagi masyarakat yang bersangkutan dalam meningkatkan pengetahuan dan keterampilan pelaku usaha (selaku petani dan keluarga tani, pengolah, dan pedagang), dalam sistem agribisnis lahan kering dimulai dari hulu hingga hilir, yaitu dari sejak sistem input, budidaya daya, pengolahan, dan pemasaran, serta penunjangnya. Dari peningkatan yang terjadi diharapkan ada perbaikan tingkat ketahanan pangan pelaku. Selanjutnya, pemerintah daerah dapat memperoleh manfaat dalam bentuk pengurangan pengangguran perdesaan dan penciptaan lapangan kerja, serta memperoleh kontribusi dari penerapan sistem agribisnis ini pada lahan kering pekarangan masyarakat Desa Gumantar, Kecamatan Kayangan, Kabupaten Lombok Utara.

\section{METODE PELAKSANAAN}

Pemanfaatan pekarangan rumah masyarakat belum optimal padahal sangat potensial untuk dimanfaatkan dengan berbagai tanaman yang sesuai. Potensi ini semakin besar karena juga didukung oleh potensi alam (lingkungan tanah dan iklim) sesuai untuk berbagai tanaman, termasuk tanaman pangan seperti sayuran, yang dapat langsung dimanfaatkan untuk memenuhi kebutuhan keluarga setempat atau pun untuk dijual ke pasar. Belum optimalnya pemanfatan sumberdaya rumahtangga (khususnya tenaga kerja keluarga dan waktu) untuk berbagai kegiatan produktif termasuk sebagai petani di 
pekarangan sendiri, pengolah hasil pertanian, maupun sebagai pedagang. Tenaga kerja dalam keluarga banyak mempunyai waktu luang terutama di musim kemarau karena pekerjaan di lahan usahatani pada waktu tersebut kurang intensif dibandingkan dengan musim hujan. Intervensi diperlukan untuk meningkatkan kondisi yang ada. Dengan berbagai upaya dan intervensi maka diharapkan masalah mitra dapat diatasi sehingga kondisi secara keseluruhan menjadi lebih baik di masa datang, yaitu terjadi peningkatan dalam ekonomi, keterampilan (skills), pengetahuan, komunikasi (termasuk jaringan ke luar wilayah desa), yang secara khusus dalam kaitan kegiatan ini adalah terjadinya peningkatan ketahanan pangan masyarakat lahan kering dari aspek produksi pangan, dan berlanjut dengan aspek akses dan kosumsi pangan, sehingga secara keseluruhan peluang pencapaian dan peningkatan ketahanan pangan menjadi lebih besar dari pada sebelumnya.
Sesuai dengan permasalahan yang dihadapi mitra, maka kegiatan pemberdayaan masyarakat ini menggunakan metode partisipatif, artinya dalam kegiatan ini masyarakat atau mitra dilibatkan dalam kegiatan perencanaan program, pelaksanaan program dan evaluasi terhadap pelaksanaan program. Dengan cara seperti ini, maka diharapkan masyarakat melakukan implementasi program berdasarkan pada kebutuhannya yang dirasakan pada awalnya atau distimulasi pada saat proses berlangsung (Guijt, 2000; Kemmis \& McTaggart, 2005; Pretty, Guijt, Scoones, \& Thompson, 1995). Dengan demikian, dalam implementasi program tersebut perlu dilakukan melalui kegiatankegiatan pelatihan/demonstrasi, diskusi, praktik terhadap materi yang disampaikan, sehingga diperoleh tidak hanya pengetahuan tetapi juga keterampilan, yang merupakan aset penting perkembangan bisnis (dan juga hidup) lebih lanjut. Materi pelatihan kegiatan disampaikan langsung oleh tim pelaksana yang 
sekaligus sebagai narasumber dalam bidang terkait dengan kegiatan pemberdayaan masyarakat ini.

\section{HASIL DAN PEMBAHASAN}

\section{Realisasi kegiatan}

Kegiatan ini dilaksanakan untuk mencapai tujuan yang telah disebutkan pada bagian tujuan kegiatan ini. Materi yang diberikan untuk penambahan pengetahuan dan/atau keterampilan adalah sesuai dengan tujuan yang telah ditetapkan. Kegiatan dilaksanakan pada tanggal 22 September 2018 di Dusun Amoramor, Desa Gumantar, Kecamatan Kayangan, Kabupaten Lombok Utara. Kegiatan dilakukan di bawah pohon dan di berugak yang ada di lokasi dekat usahatani kelompok masyarakat Dusun Amor-amor, Desa Gumantar. Peserta pelatihan terdiri atas bapak-bapak tani dan ibu-ibu tani, dan mereka dibagi menjadi 2 kelompok, yaitu kelompok bapak tani dan kelompok ibu tani.

Materi penyuluhan adalah seperti telah dirincikan pada bagian pelaksanaan kegiatan, yaitu meliputi: Pemanfaatan lahan pekarangan untuk pertanian yang produktif (Badan Litbang Pertanian RI, 2017); Pemanfaatan sumberdaya manuasia dalam rumahtangga (tenaga kerja dan waktu); Teknologi pertanian vertikultur; Keputusan pemilihan usaha (termasuk jenis tanaman) berdasarkan Sjah (2010); Panen, pasca panen, dan pengolahan hasil pertanian berdasarkan Zainuri dkk (2017); Pemasaran produk berdasarkan (Kotler \& Susanto, 2001; Swastha \& Irawan, 2005); Penerapan sistem agribisnis (Asriani, 2003; Gumbira-Said \& Intan, 2001; Saragih, 2004); Manajemen usaha (Covello \& Hazelgren, 2004; Sjah dkk, 2012); dan lain-lain yang terkait. Materi penyuluhan disampaikan secara bergilirian antar kelompok bapak dan ibu tani dan juga antar pelaksana penyuluhan (pemateri), sehingga kedua kelompok memperoleh semua materi yang disuluhkan.

\section{Metode pelaksanaan}

Peserta pelatihan merupakan para petani pria (bapak tani) dan wanita (ibu tani). Kelompok wanita menerima materi penyuluhan di baah pohon, sedangkan kelompok 
pria menerima penyuluhan di berugak. Jumlah peserta dibatasi hingga 20 orang saja untuk mendapatkan efektivitas kegiatan. Ukuran kelas ini sesuai dengan banyak teori efektivitas pengajaran yang dikemukakan dalam proses belajar mengajar. Dalam praktiknya, tim penyuluh memperkirakan bahwa peserta penyuluhan dapat mendengarkan materi yang disampaikan, sehingga diharapkan timbul pemahaman terhadap informasi yang disampaikan.

Metode yang digunakan dalam pelatihan ini adalah metode ceramah dan diskusi. Ceramah disertai dengan peragaan untuk memfasilitasi pemahaman peserta penyuluhan. Kegiatan ini berlangsung dari pukul 11.00 sampai 16.00 .

\section{Evaluasi kegiatan}

Kegiatan telah dilaksanakan sesuai dengan rencana, termasuk tentang materi, waktu, dan hasil yang diharapkan. Dengan kata lain, pelaksanaan kegiatan ini dinilai efektif. Efektivitas hasil diperkuat dengan komunikasi yang baik, interaktif, dan berkelanjutan selama pelatihan dan setelah selesainya kegiatan penyuluhan ini. Peserta pelatihan menanyakan banyak hal kepada narasumber dan mereka antusias. Tim penyuluh juga sangat bersimpati terhadap kesulitan yang sedang dialami oleh peserta penyuluhan, yang sebagina masih merasakan kesedihan dan shock karena kejadian gempa yang berulang-ulng di lokasi tersebut dan dengan skala gempa yang relatif besar dan telah berdampak merusak bangunan, bahkan lahan. Beberapa peserta menyatakan bahwa mereka akan memanfaatkan materi pelatihan untuk dipraktikkan di pekarangan mereka. Peserta juga berhasrat untuk mendapatkan pelatihan tambahan dan bimbingan lanjutan dalam beberapa aspek, antara lain aspek kehidupan tanaman dan bisnisnya, agar manfaat kegiatan dapat dirasakan.

Faktor pendukung dan penghambat kegiatan

Ada cukup banyak faktor yang mendukung pelaksanaan kegiatan penyuluhan ini dan pelaksanaan 
hasil-hasilnya. Termasuk sebagai faktor pendukung ini adalah antusiasme dan kesadaran peserta untuk meningkatkan kondisi perekonomian mereka, terutama karena terdampak negatif dari gempa yang terjadi. Faktor ini menggerakkan mereka (petani dan keluarga) untuk mengikuti kegiatan penyuluhan dan kemudian mengaplikasikan dengan kaidah (agri) bisnis.

Selain itu, masyarakat desa setempat merupakan masyarakat yang suka bekerjasama untuk kepentingan bersama (bergotong royong merupakan tradisi yang rajin dipraktikan). Kondisi ini merupakan modal untuk maju bersama dalam suatu bisnis, termasuk agribisnis yang bisa dikelola secara kelompok, ataupun secara individual.

Sebaliknya ada juga faktor penghambat seperti jarak lokasi yang cukup jauh sehingga agak menyulitkan untuk bisa sering-sering bertemu dengan anggota kelompok masyarakat lainnya. Demikian juga dengan jauhnya desa ini dengan pusat-pusat ekonomi sehingga untuk pemasaran produk akan memerlukan transportasi yang jauh dan biaya yang relatif tinggi. Di atas semua hambatan yang telah disebutkan juga ada kondisi yang belum tenang dan belum nyaman dalam kehidupan mereka Oleh karena itu, faktorfaktor yang menghambat ini perlu dipikirkan pemecahannya, antara lain dengan membangun atau memperbaiki kondisi jalan dan perumahan penduduk.

\section{KESIMPULAN DAN SARAN}

\section{Kesimpulan}

Kegiatan penyuluhan seperti ini perlu dilakukan karena dibutuhkan oleh masyarakat setempat dan potensi sumberdaya alam dan sumberdaya manusia untuk melakukan kegiatan tersebut cukup besar. Pelatihan yang dilakukan dinilai efektif dan masyarakat tergerak untuk mengaplikasikan pengetahuan dan keterampilan yang telah diperoleh dalam bentuk menjalankan usaha secara lebih baik dari pada sebelumnya. Sikap mental peserta penyuluhan dinilai baik dan 
mendukung untuk pengembangan

usaha pekarangan untuk kehidupan.

Saran

Karena hasil positif dan efektif dari kegiatan yang telah dilaksanakan maka kegiatan semacam ini perlu diperbanyak di lokasi desa setempat, atau ke lokasilokasi baru sesuai dengan potensi wilayah yang bersangkutan. Secara khusus pemerintah, melalui dinasdinas terkait, diharapkan lebih banyak berperan dalam kaitan ini, sehingga peluang-peluang untuk meningkatkan kondisi kehidupan tidak terlewat begitu saja.

\section{DAFTAR PUSTAKA}

Asriani, P. S. 2003. Konsep agribisnis dan pembangunan pertanian berkelanjutan di Indonesia. Agrisep, 1(2): 144-150.

Badan Litbang Pertanian RI. 2017. Kawasan Rumah Pangan Lestari Jakarta: Kementerian Pertanian Republik Indonesia.

BPS Lombok Utara. 2016. Lombok Utara Dalam Angka 2016 (North Lombok in Figures 2016). Tanjung: Badan Pusat Statistik Lombok Utara (Central Body of Statistics of North Lombok).

Covello, J. A., \& Hazelgren, B. J. 2004. Rencana Bisnis
Lengkap (The complete book of business plans). Batam: Interaksara.

Guijt, I. 2000. Methodological issues in participatory monitoring and evaluation. In $\mathrm{M}$. Estrella, J. Blauert, D. Campilan, J. Gaventa, \& R. Ricafort (Eds.), Learning from change: Issues and experiences in participatory monitoring and evaluation: 201-216. London \& Ottawa: ITPL \& IDRC.

Gumbira-Said, E., \& Intan, A. H. 2001. Manajemen Agribisnis. Jakarta: Ghalia Indonesia.

Kemmis, S., \& McTaggart, R. 2005. Participatory action research: Communicative action and the public sphere. In N. K. Denzin, \& Y. S. Lincoln (Eds.), The Sage Hanbook of Qualitative Research, 3rd ed.: 559-604. Thousand Oaks, California: Sage Publications.

Kotler, P., \& Susanto, A. B. 2001. Manajemen Pemasaran di Indonesia: Analisis, Perencanaan, Implementasi dan Pengendalian (A. A. Hermawan, Trans.) (1 ed.). Jakarta: Salemba Empat.

Menteri Pertanian RI. 2015. Rencana Strategis Kementerian Pertanian Tahun 2015 - 2019 Jakarta: Kementerian Pertanian Republik Indonesia.

Pretty, J. N., Guijt, I., Scoones, I., \& Thompson, J. 1995. A trainer's guide for participatory learning and action. London: International 
Institute for Environment and Development.

Saragih, B. 2004. Pembangunan pertanian dengan paradigma sistem dan usaha agribisnis. Jakarta.

Sjah, T. 2010. Ekonomi Pertanian. Mataram: Mataram University Press.

Sjah, T., Rosmilawati, \& Zainuri. 2012. Rencana Bisnis: Untuk pengusaha kecil dan pemula dalam usaha pengolahan hasil pertanian. Mataram: Mataram University Press.
Swastha, B., \& Irawan. 2005. Menejemen Pemasaran Modern (2 ed.). Yogyakarta: Liberty.

Zainuri, Handayani, B. R., Werdiningsih, W., \& Widyasari, W. 2017. Modul pelatihan pengolahan hasil pertanian untuk meningkatkan ekonomi perempuan di Kabupaten Lombok Utara. Mataram: Konsorsium Karya TerpaduMCAI. 